\title{
Characterization of the Penicillin G Acylase from Bacillus megaterium ATCC 14945
}

\author{
Vanessa Ribeiro de Souza ${ }^{1}$, Ana C. G. Silva ${ }^{1}$, Laura Marina Pinotti ${ }^{2}$, Heloísa Sobreiro \\ Selistre Araújo ${ }^{2}$ and Raquel de Lima Camargo Giordano ${ }^{1 *}$ \\ ${ }^{1}$ Departamento de Engenharia Química; ${ }^{2}$ Departamento de Ciências Fisiológicas; Universidade Federal de São \\ Carlos; Via Washington Luiz, Km 235; 13565-905; São Carlos - SP - Brasil
}

\begin{abstract}
The purpose of this work was to characterize the enzyme penicillin $G$ acylase (PGA) produced by Bacillus megaterium. Purification of the enzyme by ultra/diafiltration did not allow the detection of the PGA band by SDSPAGE electrophoresis due to the high content of remaining proteins. However, using the DNA of the microorganism, it was possible to replicate the genes of the two $\mathrm{B}$. megaterium PGA reported in literature, showing that the enzyme consisted of two sub-units, having 245 and 537 amino acids each and an average molecular mass of 26950 and $59070 \mathrm{Da}$, respectively. The parameters studied were: 1) the influence of temperature in the 25-60 $\mathrm{C}$ range, 2) $\mathrm{pH}$ in the 5-10 range and 3) substrate concentration, this was tested to obtain results on the Penicillin $G$ hydrolysis reaction rate, using the initial velocities approach. The maximum hydrolysis rate was obtained at $37^{\circ} \mathrm{C}$ and $\mathrm{pH}$ 8.0. The Michaelis-Menten model fitted well, resulting in estimated $K_{m}$ and $V_{\text {max }}$ parameters values of 1.83 $\mathrm{mM}$ and $0.165 * 10^{-3} \mathrm{mmol} / \mathrm{min} / \mathrm{UI}$, respectively.
\end{abstract}

Keys words: Penicillin G acylase, Bacillus megaterium, characterization

\section{INTRODUCTION}

The 6-aminopenicilanic acid, 6-APA, is an intermediary product in the production of semisynthetic penicillin, such as amoxycillin and ampicillin. It can be obtained industrially via penicillin $\mathrm{G}$ hydrolysis catalyzed by immobilized penicillin $G$ acylase. These antibiotics have application as therapeutic agents, increasing world production of 6-APA (Shewale and Sivaraman, 1989).

Commercially the principal $\beta$-lactamics constitute the greatest market of antibiotics in the world. Modern biotechnological techniques and computational resources have boosted the "biotechnological revolution", which anticipates the growth of the industrial enzyme market to be from \$395 million in 1997 to $\$ 731$ million in 2004 (Frost and Sullivan - http://www.frost.com). The $\beta$-lactamic group contributes $3 \times 10^{7} \mathrm{~kg} /$ year to the total of $5 \times 10^{7} \mathrm{~kg} /$ year produced in the world. It is estimated that 10-30 range million tons of immobilized PGA are utilized each year (Gómez, 1994).

Penicillin $\mathrm{G}$ acylase can be produced by different microorganisms, but comparative studies are rare between them. Escherichia coli has been studied the most. Bacillus megaterium secretes the enzyme produced, simplifying the separation process.

The PGA production by $B$. megaterium has been studied by Pinotti et al., (2000 and 2002) aiming to increase the final enzyme concentration in the

\footnotetext{
* Author for correspondence
} 
culture medium. Enzyme characterization is necessary to compare its properties with those produced by other microorganisms.

The study of Konstantinovic et al., (1994) reported the gene sequence that codified the PGA from Arthrobacter viscosus ATCC 15294. The sequence presented 2406 nucleotides with $37 \% \mathrm{C}+\mathrm{G}$ genetic content. This sequence codified the precursor polypeptide chain of 802 amino acids. The first 26 amino acids belonged to the signal peptide. The $\alpha$ and $\beta$ chains were separated by spacer peptides and had 208 and 537 amino acids, respectively. Martín et al., (1995) carried out a similar study but with gene pAC from B. megaterium ATCC 14945 (both microorganisms expressed the enzyme extra cellularly). The authors sequenced these genes and cloned in E. coli HB101. The sequence presented 2406 nucleotides with $37 \% \mathrm{C}+\mathrm{G}$ of genetics content, codifying a polypeptide chain of 802 amino acids. The comparison of the amino acids sequence from $B$. megaterium $\mathrm{PGA}$ with $K$. citrophila PGA and $K$. citrophila PGA showed that all PGAs belonged to the same protein family. B. megaterium enzyme presented higher similarity with A. viscosus PGA, 97\% resemblance with regard to amino acids and $98 \%$ to nucleotides.

An inert extract of culture medium contains, alongside the enzyme of interest, other substances, including other proteins. The characterization of the enzyme of interest with regard to molecular mass determination requires enzyme concentration and purification. There are various techniques that can be applied to determine the molecular mass of the protein. SDS-PAGE electrophoresis is the most studied and applied.

Purification methodologies utilize different techniques that frequently result in activity damage to the enzyme of interest The purification strategy should outline how it affects the global process cost and the enzyme applicability (Ausubel, 1999).

The extract filtration using ultra filtration membranes with adequate molecular cut off weight allows a fine grade purification, and then preferential permeation of substances smaller than the proteins is carried out. The sequential use of diafiltration allows more accentuated removal of theses substances, with retention of the goal protein. The ultra/diafiltration combination permits an expressive increase in the purity of the extract. Cheang and Zydney (2003) utilized the combined ultra/diafiltration process separating $\alpha$ -
Lactoalbumin and $\beta$-Lactoglobulin proteins, with a selectivity equal to 55, purification factor of 100 and $90 \% \quad \beta$-Lactoglobulin recuperation as the retained product. The $\alpha$-lactoalbumin was recuperated with purification factor above 10 and efficiency at $99 \%$, approximately.

The chemical kinetic analyzes and characterizes the factors that influence the chemical reaction velocity, such as $\mathrm{pH}$, temperature and substrate concentration. The optimum $\mathrm{pH}$ and temperature determination, as well as the kinetic model (that represents the substrate concentration influence) are very important when utilizing the enzyme in industry and can be varied according to the substrate applied and enzyme source. Self et al., (1969) and Azevedo et al., (1999), studied the hydrolysis kinetics of 6-nitro-3-(phenylacetamido) benzoic acid (NIPAB) catalyzed by soluble PGA from $E$. coli ATCC 9637 (pH 7.0 and $37^{\circ} \mathrm{C}$ ) and determined $\mathrm{K}_{\mathrm{m}}$ values of $1.7 \mathrm{mmol} . \mathrm{dm}^{-3}$ and $0.0564 \mathrm{mmol}^{-\mathrm{dm}^{-3}}$.

$\mathrm{K}_{\mathrm{m}}$ values for penicillin $\mathrm{G}$ hydrolysis reported in literature vary according to the enzyme source. Savidge and Cole (1975), studying penicillin G hydrolysis, obtained $\mathrm{K}_{\mathrm{m}}$ values equal to 7.7 and $4.5 \mathrm{mM}$ for $E$. coli and B. megaterium PGA, respectively.

The purpose of this work was to determine the $B$. megaterium PGA molecular mass and enzyme kinetic properties such as optimum $\mathrm{pH}$ and temperature and kinetic parameters.

\section{MATERIALS AND METHODS}

\section{Enzyme}

Penicillin $G$ acylase was excreted from $B$. megaterium fermentation broth. The fermentation carried out in culture medium initially contained free amino acids donated by Ajinomoto S/A $(10.0 \mathrm{~g} / \mathrm{l})$, cheese whey - Sigma $(19.6 \mathrm{~g} / \mathrm{L})$, minerals salts - Synth and Mallinckrodt and $(0.2 \mathrm{~g} / \mathrm{L})$ and inductor phenyl acetic acid - Carlos Erba (2.7g/L).

\section{Reagents}

The reagents utized for different analysis were: Potassic penicillin G - Cipan; methanol, acetic acid, sodium hydroxide - Synth; p-dimethylaminobenzaldehyde (PDAB) - Mallinckrodt. Other 
different trade mark reagents common in laboratories.

\section{Determination of the enzymatic activity}

The initial velocity of the penicillin G hydrolysis, under standard conditions (penicillin G 4\%w/v prepared in phosphate buffer $200 \mathrm{mM}, \mathrm{pH} 8.0$ at $37^{\circ} \mathrm{C}$ ), was defined as the enzyme activity. 6amino-penicillanic acid (6-APA) was produced via a hydrolysis reaction which took place in a jacketed glass reactor $(50 \mathrm{~mL})$, connected to a thermostatically controlled bath (Brookfield EX 200). The 6-APA was reacted with PDAB and then estimate by measuring the absorbance at 415 nm with a spectrophotometer (Ultrospec 2000). This procedure was carried out as described by Balasingham et al. (1984). One international unit (IU) is the enzyme quantity that catalyzes the formation of $1 \mu \mathrm{mol} 6$-APA per minute, under standard reaction conditions (PenG $4 \% \mathrm{w} / \mathrm{v}, 37^{\circ} \mathrm{C}$ and $\mathrm{pH}$ 8.0).

\section{Determination of the protein content}

The Bradford method, (1976) was utilized to determine protein content. $5 \mathrm{~mL}$ of Bradford reagent was added to a $100 \mu 1$ sample $\left(C_{\text {protein }}\right.$ total $<600 \mathrm{mg} / \mathrm{L})$. After agitation in a vortex and resting for 5 minutes, the absorbance was measured in a spectrophotometer at $595 \mathrm{~nm}$. The calibration curve was obtained with albumin serum solutions.

\section{Gene amplification of Bacillus megaterium PGA}

Initially, genomic $B$. megaterium DNA was extracted according to the Gibco protocol, utilizing DNAzol reagent for cellular membrane permeabillization. Primers and microorganism DNA were incubated in a thermocycler - Perkin Elmer - so that for each low temperature cycle, the Taq-polimerase enzyme duplicated fragments of signalized DNA by initializing sequences and each high temperature cycle, the oligonucleotides formed were available to produce new copies. The material produced was submitted to electrophoresis on agarose gel $1 \%$ to verify the oligopeptides molecular mass. The bands formed were visualized in a transilluminater and photographed with a Kodak digital camera.
Determination of the optimum $\mathrm{pH}$ and temperature and kinetic reaction parameters $\mathbf{V}_{\max } \mathbf{e} \mathbf{K}_{\mathrm{m}}$

The enzyme activity to determine the optimum $\mathrm{pH}$ (reaction initial velocity) was measured in penicillin $\mathrm{G} 4 \% \mathrm{w} / \mathrm{v}$ solutions as substrate at different $\mathrm{pH}$ values, prepared using different buffers 200mM: borate (pHs 9.0 and 10.0); phosphate $(\mathrm{pH} 7.0$ and 8.0) and citrate $(\mathrm{pH} 5.0$ and 6.0) at $37^{\circ} \mathrm{C}$. To determine the optimum temperature, the enzyme activity was measured via the penicillin $\mathrm{G} 4 \% \mathrm{w} / \mathrm{v}$ hydrolysis at different temperatures $\left(25-60^{\circ} \mathrm{C}\right)$, in phosphate buffer, $\mathrm{pH}$ 8.0.

The influence of the substrate concentration PenG - was investigated via initial reaction velocity for initial different PenG concentrations, $0.5-10 \mathrm{mM}$ range at $37^{\circ} \mathrm{C}$ diluted in phosphate buffer $200 \mathrm{mM}$ and $\mathrm{pH} 8.0$. The reaction was conduced in a jacketed glass reactor, with water circulation for temperature control being conducted to a thermostatically controlled bath (Brookfield EX 200).

\section{Micro-Ultra and Diafiltration}

Four liters of fermentation broth, maintained on ice, were initially pumped through the membrane (Milipore Pellicon), having a porosity of $0.45 \mu \mathrm{m}$ for $B$. megaterium cell separation. The micro filtrate broth containing PGA and other possible excreted proteins, cheese whey proteins and other solutes of smaller molecular mass, were concentrated by ultrafiltration in a mini Pellicon unit with a molecular cut-off weight (MWCO) 50 $\mathrm{kDa}$. The concentrated filtrate was submitted to a diafiltration, through an ester cellulose membrane (MWCO $10 \mathrm{kDa}$ ) using 2 liters of phosphate buffer 200mM, pH 8.0.

\section{Electrophoresis}

SDS-PAGE Electrophoresis of protein was carried out in a vertical mini-unit - (Pharmacia Biotech). The operational conditions were: acryl amide gel $12 \%, 8 \mu \mathrm{L}$ of concentrate fermentative broth, standard containing $576 \mu \mathrm{g}$ of: phosphorylase-b (97 $\mathrm{kDa})$, albumin (66 kDa), ovoalbumin (45 kDa), carbonic anydrase $(29 \mathrm{kDa})$, and trypysin inhibitor (20.1 kDa). 


\section{RESULTS AND DISCUSSION}

\section{PGA molecular mass}

The fermentative broth was concentrated by ultradiafiltration aiming at applying the SDS gel electrophoresis to determine the molecular mass of the enzyme. The original microfiltrate extract containing $152 \mathrm{IU}$ PGA/L and $0.72 \mathrm{~g} / \mathrm{L}$ protein, reached $1050 \mathrm{IU} / \mathrm{L}$ and $3.10 \mathrm{~g} / \mathrm{L}$ protein via ultrafiltration (MWCO 50kDa) with a 10 fold volumetric concentration factor. The sequential diafiltration reduced the final activity to $928 \mathrm{IU}$ $\mathrm{PGA} / \mathrm{L}$ and the total protein to $1.56 \mathrm{~g} / \mathrm{L}$. By applying SDS gel electrophoresis, it was seen that the concentration and purification grade reached by ultra-diafiltration was not sufficient to differentiate PGA into two sub-units due to the presence of the reminiscent proteins in the broth. Assays to amplify these genes by PCR (polymerized chain reaction) were carried out in a parallel work aiming to clone the $B$. megaterium PGA in E. coli.

For gene amplification, initial sequences (primers) previously synthesized with regard to the gene sequence reported by Martin et al., (1995), were utilized. Two primers were necessary, each one complementary to one of the DNA Double-helix strands and positioned on opposite sides in the region to be amplified. Therefore, the forward primer was complementary to the nucleotide sequence corresponding to the PGA gene and the reverse primer was complementary to the final PGA gene fragment.

These experiments allowed an amplification of two sub units contained in the gene, utilizing initial sequences projected from the hypothesis that the enzyme produced was the same as the one sequenced by Martín et al., (1995). Two sub units were amplified, each one with 245 and 537 amino acids and average molecular mass equal to 26950 and $59070 \mathrm{Da}$, respectively, similar to those amplified by Martin et al, (1995). Therefore, the enzyme was constituted of two sub units having total molecular mass of $86020 \mathrm{Da}$.

\section{Influence of $\mathrm{pH}$ and temperature on the PGA activity}

The majority of the enzymes present a characteristic $\mathrm{pH}$ value where its activity is maximum. Above and below this $\mathrm{pH}$, the activity reduces. The enzyme's three-dimensional structure, responsible for its catalytic activity, is stabilized by a hydrogen bond, hydrophobic interaction and a di-sulfate bond.

Altering the hydrogen concentration modifies the equilibrium of theses forces, irreversibly deactivating the enzyme. Other factors where enzymatic activity is related to $\mathrm{pH}$ depend on the enzyme's acid and alkaline behavior and the substrate itself (Voet, 1995).

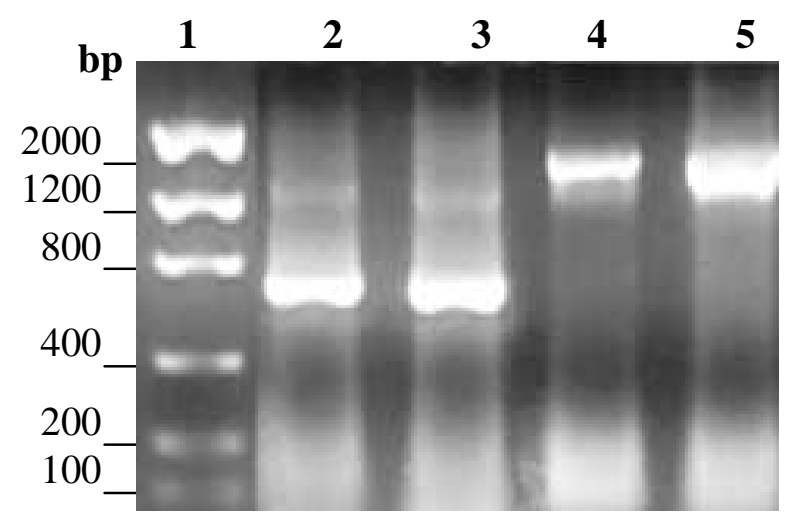

Figure 1- Electrophoresis gel of material originating from the B. megaterium DNA amplification: 1 - DNA standard of small molecular mass; 2 and 3 - amplification product of penicillin $G$ acylase Alfa sub unit; 4 and 5 - amplification product of penicillin $\mathrm{G}$ acylase Beta sub unit. 
Generally just one of the ionic substrate forms is accepted by the enzyme and its concentration (neutral or charged form) depends on the $\mathrm{pH}$. Still, if an amino acid residue is directly involved in the catalyzation, the charged or neutral form of this residuewill be acting. In the case of the E.coli PGA, the amine group of the final serine present in the Beta sub-unit is responsible for the proton $\mathrm{H}^{+}$ attraction of the $\mathrm{OH}^{-}$group present in the serine residue (Duggleby, 1995). Only when this proton is attracted, the oxygen acquires enough force to bond the penicillin $G$ amide, releasing phenyl acetic acid and 6-APA. The maximum activity of this enzyme is directly related to the $\mathrm{pK}$ value of the amine group of the final serine. These similarities between the molecular mass of the two PGA sub-units suggest a similar kinetic behavior for both enzymes. With respect to the temperature effect, as occurs with all chemical reactions, the reaction velocity catalyzed by enzyme increases exponentially with temperature increase over a determined range in which enzyme is stable. Since enzymes are fragile proteic structures projected to operate at physiological temperatures, when used at temperature above $37^{\circ} \mathrm{C}$, they loose their activity due to the denaturing of various enzyme molecules present as the temperature or the reaction time increase.

Tables 1 and 2 show B. megaterium PGA activity with $\mathrm{pH}$ variation at $37^{\circ} \mathrm{C}$ and with temperature variation at $\mathrm{pH}$ 8.0, for penicillin $\mathrm{G}$ hydrolysis. The results showed that maximal enzyme activities occured at $\mathrm{pH} 8.0$ and $37^{\circ} \mathrm{C}$. E.coli PGA presented maximum activity at $\mathrm{pH} 7.0$ and $37^{\circ} \mathrm{C}$.

Table 1 - Enzymatic Activity of the B. megaterium penicillin G acylase at different $\mathrm{pHs}$ and $37^{\circ} \mathrm{C}$ for penicillin $\mathrm{G}$ hydrolysis.

\begin{tabular}{cc}
\hline $\mathbf{p H}$ & $\begin{array}{c}\text { Enzymatic Activity } \\
\text { (IU/L) }\end{array}$ \\
\hline 5 & 0 \\
6 & 236.0 \\
7 & 322.0 \\
8 & 348.0 \\
9 & 248.3 \\
10 & 226.1 \\
\hline
\end{tabular}

Table 2 - Enzymatic Activity of the B. megaterium penicillin G acylase at different temperatures and $\mathrm{pH} 8.0$ for penicillin G hydrolysis.

\begin{tabular}{c|c}
\hline $\begin{array}{c}\text { Temperature } \\
\left({ }^{\circ} \mathbf{C}\right)\end{array}$ & Enzymatic Activity (IU/L) \\
\hline 25 & 207.0 \\
30 & 270.5 \\
37 & 348.0 \\
45 & 209.8 \\
50 & 126.0 \\
60 & 0 \\
\hline
\end{tabular}

\section{Influence of substrate concentration}

The effect of substrate concentration on the activity of $B$. megaterium PGA was investigated by performing reactions at different penicillin $G$ concentrations. The selection of the reaction time was chosen in such a way that conversions smaller than $10 \%$ occurred. In this case, the product concentrations were reduced; where the possible inhibitory effects of such product became insignificant as occurred in the reverse reaction (if the reaction was reversible). Since the kinetics of the majority of enzymatic reactions are represented by the Michaelis-Menten model, this was adjusted to experiment with initial velocity points obtained via the penicillin $G$ hydrolysis at different concentrations. The slope of the product concentration versus time curve, determined from the initial linear phase of reaction represented the initial velocity for each initial substrate concentration. Table 3 shows the initial velocities of penicillin $\mathrm{G}$ hydrolysis catalyzed by $B$. megaterium PGA for different substrate concentrations. 
Table 3 - Initial velocities of penicillin G hydrolysis catalyzed by B. megaterium PGA for different penicillin G concentrations.

\begin{tabular}{c|c}
\hline PenG Concentration $(\mathbf{m M})$ & $\begin{array}{c}\text { Initial Velocity } \\
\left(\mathbf{m M}_{\text {PenG. }} \mathbf{m i n}^{-1}\right)\end{array}$ \\
\hline 0,5 & 0.0094 \\
1 & 0.0135 \\
2 & 0.0157 \\
10 & 0.0222 \\
\hline
\end{tabular}

Table 4 - Kinetic parameters values and respective error obtained by the Michaelis-Menten adjustment made to experiment points of the penicillin G hydrolysis catalyzed by soluble B. megaterium PGA

\begin{tabular}{c|c|c}
\hline $\begin{array}{c}\text { Kinetic } \\
\text { Parameters }\end{array}$ & $\begin{array}{c}\text { Estimate } \\
\text { Values }\end{array}$ & Error \\
\hline $\begin{array}{c}\mathrm{V}_{\max } \\
\left(\mathrm{mM}_{\mathrm{PenG}} / \min * \mathrm{IU}\right) \\
\mathrm{K}_{\mathrm{m}}\end{array}$ & $0.165 * 10^{-3}$ & \pm 0.0035 \\
$(\mathrm{mM})$ & 1.83 & \pm 0.53 \\
\hline
\end{tabular}

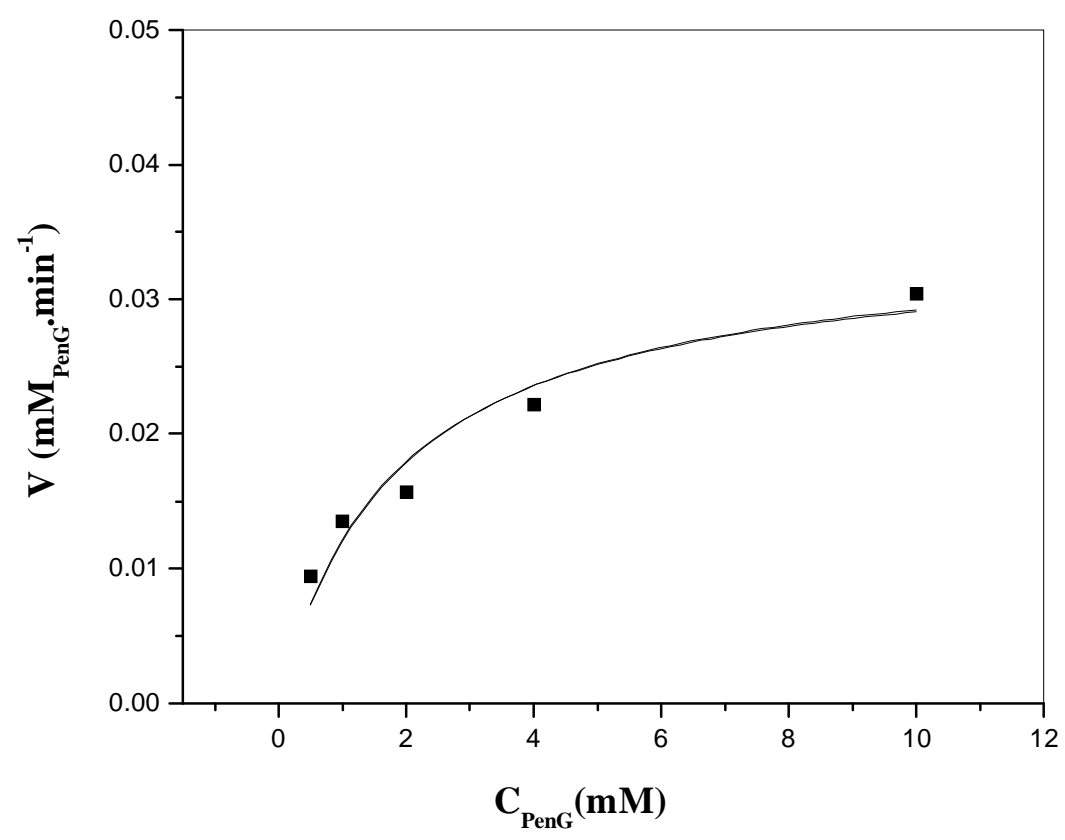

Figure 2 - The Michaelis-Menten model adjusted to initial velocities of penicillin G hydrolysis, determined for various initial substrate concentrations at $\mathrm{pH}$ 8.0 and $37^{\circ} \mathrm{C}$ catalyzed by soluble B. megaterium PGA.

The Michaelis-Menten model was adjusted to the experiments points (Microcal Origin 6.0 software), aiming to determine kinetic parameters. The adjustment was initiated utilizing parameters estimated from linear adjustment points of the reverse velocity versus reverse substrate concentration curve (Lineweaver-Burk plot).
Savidge and Cole (1975) studied penicillin G hydrolysis and obtained $\mathrm{K}_{\mathrm{m}}$ values equal to 7.7 and $4.5 \mathrm{mM}$ for $E$. coli and $B$. megaterium PGA, respectively at $37^{\circ} \mathrm{C}$ and $\mathrm{pH} 8.7$. The $\mathrm{K}_{\mathrm{m}}$ value estimate for E.coli PGA was $1.48 \mathrm{mM}$ at $37^{\circ} \mathrm{C}$ and pH 8.0 (Modesto, 2002). Since the MichaelisMenten constant measured the affinity between 
enzyme and substrate, the values suggested that $B$. megaterium PGA had the highest affinity to penicillin G. The estimated value for $B$. megaterium PGA was reasonably similar to values reported in literature.

\section{ACKNOWLEDGMENTS}

The authors wish to thank FAPESP, CNPq and PADCT-CNPq for financial support.

\section{RESUMO}

O objetivo deste trabalho foi caracterizar a enzima penicilina $\mathrm{G}$ acilase (PGA) produzida por Bacillus megaterium, uma importante enzima industrial que catalisa a hidrólise de penicilina $\mathrm{G}$, para produção de antibióticos semi-sintéticos. Purificação da enzima por ultra/diafiltração não permitiu detectar a banda de PGA por eletroforese SDS-PAGE devido ao elevado conteúdo de outras proteínas remanescentes. Contudo, utilizando DNA do microrganismo que vem sendo estudado, foi possível amplificar os genes das duas subunidades de PGA previstas na literatura, mostrando que a enzima em estudo é também constituída de duas sub-unidades, 245 e 537 aminoácidos cada, com massas moleculares médias de 26950 e 59070 Da, respectivamente. Foram estudadas as influências da temperatura 25$60^{\circ} \mathrm{C}, \mathrm{pH} 5-10$, e concentração do substrato na velocidade da reação de hidrólise da penicilina $\mathrm{G}$. A temperatura e $\mathrm{pH}$ ótimos foram de $37^{\circ} \mathrm{C}$ e 8,0 , respectivamente. $\mathrm{O}$ modelo de Michaelis-Menten representou bem a cinética da reação, com valores de parâmetros estimados de $1,83 \mathrm{mM}$ para $\mathrm{Km}$ e $\mathrm{V}_{\text {máx }}=0,165^{*} 10^{-3} \mathrm{mmol} / \mathrm{min} / \mathrm{UI}$.

\section{REFERENCES}

Ausubel, F. M.; Brent, R.; Kingston, R. E.; Moore, D. D.; Seidman, J. G.; Smith, J. A. and Struhl, K. (Eds.) (1999), Short protocols in molecular biology: A Copendiun of Methods from Current Protocols in Molecular Biology. 14 ${ }^{\text {th }}$ ed. New York : John Wiley.

Balasingham, K.; Warburton, D.; Dunnill, P. and Lilly, D. (1984), Enzymatic conversion in aqueous twophase system: Deacylation of benzylpenicillin to 6aminopenicilanic acid with penicillin acylase. Enzyme Microb. Technol., 6, 301-306.
Bradford, M. M. (1976), A rapid and sensitive method for the quantities of protein utilizing the principle of protein-dye binding. Analytical Biochemistry, 72, 248-54.

Cheang, B. and Zydney, A. (2003), Separation of $\alpha$-Lacto albumin and $\beta$-Lacto globulin using membrane ultra filtration, Biotechnology and Bioengineering, 83 : (2), 201-209.

Duggleby, H. J.; Tolley, S. P.; Dodson, E. J. and Moody, P. C. E. (1995), Penicillin acylase has a single- amino-acid cata. Nature, 373, 264-8.

Gómez, A. et al. (1994), Strategies in the design of a Penicillin Acylase Process. Cuernavaca: Instituto de Biotecnologia.

Lehninger, A. L. (1991), Princípios de Bioquímca. São Paulo : Sarvier. pp. 127-194.

Martín, L.; Prieto, M. A.; Cortés, E. and García, J. L. (1995), Cloning and Sequencing of the pac Gene Encoding the Penicillin G Acylase of Bacillus megaterium ATCC 14945. FEMS Microbiology Letters, 125, 287-292.

Modesto, M. (2002), Estimativa de Parâmetros Cinéticos Inerentes de Enzimas Imobilizadas. Trabalho de graduação no curso de Engenharia Química da UFSCar, São Carlos.

Pinotti, L. M.; Silva, R. G.; Giordano, R. C. and Giordano, R. L. C. (2002), Inoculum Studies in Production of Penicillin G Acylase by Bacillus megaterium ATCC 14945. Applied Biochemistry and Biotechnology, Totowa, New Jersey, 98-100, 679-686.

Pinotti, L. M.; Silva, A. F. S.; Silva, R. G. and Giordano, R. L. C. (2000), Study of Different Media for Production of Penicillin G Acylase from Bacillus megaterium ATCC 14945. Applied Biochemistry and Biotechnology, Totowa, New Jersey - USA, 84-86, 655-677.

Savidge, T. A. and Cole, M. (1975), Penicillin Acylase (bacterial). Methods in Enzymology, 43, 705-721.

Segel, I. H. (1975), Enzyme Kinetics. New York, John Wiley and Sons, Inc., capítulos 1, 2, 3, 4 e 11.

Shewale, J. G. and Sivaraman, H. (1989), Penicillin Acylase: Enzyme production and its application in the manufacture of 6-APA, Proc. Biochem., 146-154.

Voet, J. G. (1995), Biochemistry. 2.ed. NY, USA : John Wiley and sons.

Konstantinovic, M.; Marjanovic, N.; Ljubijankic, G. and Glisin, V. (1994), The Penicillin amidase of Arthrobacter viscosus (ATCC 15294). Gene, 143, 79-83. (http://www.frost.com, mar. 2004).

Received: September 29, 2004; Revised: February 25, 2005; Accepted: March 25, 2005. 